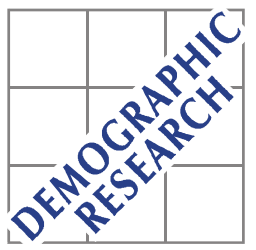

Demographic Research a free, expedited, online journal

of peer-reviewed research and commentary in the population sciences published by the Max Planck Institute for Demographic Research

Konrad-Zuse Str. 1, D-18057 Rostock · GERMANY

www.demographic-research.org

DEMOGRAPHIC RESEARCH

VOLUME 17, ARTICLE 2, PAGES 23-58

PUBLISHED 26 JULY 2007

http://www.demographic-research.org/Volumes/Vol17/2/

DOI: 10.4054/DemRes.2007.17.2

Research Article

\title{
Attitudes towards abortion and contraception in rural and urban Burkina Faso
}

\section{Clémentine Rossier}

(C) 2007 Rossier

This open-access work is published under the terms of the Creative Commons Attribution NonCommercial License 2.0 Germany, which permits use, reproduction \& distribution in any medium for non-commercial purposes, provided the original author(s) and source are given credit.

See http:// creativecommons.org/licenses/by-nc/2.0/de/ 


\section{Table of Contents}

1 Introduction $\quad 24$

2 Two preliminary qualitative investigations 26

$2.1 \quad$ Methods and data 26

$2.2 \quad$ Meanings and practices of different modes of birth control in rural 27

2.3 Meanings and practice of different modes of birth control in urban 29 Burkina Faso

$3 \quad$ Constructing quantitative attitudinal scales on birth control 31

3.1 Designing the data collection tools 32

$\begin{array}{lll}3.2 & \text { The rural and urban samples } & 37\end{array}$

$\begin{array}{lll}3.3 & \text { Analyzing attitudinal data } & 37\end{array}$

$4 \quad$ Results $\quad 38$

$\begin{array}{llr}5 & \text { Discussion } & 49\end{array}$

6 Conclusion $\quad 53$

$\begin{array}{llr}7 & \text { Acknowledgements } & 53\end{array}$

$\begin{array}{ll}\text { References } & 55\end{array}$ 


\title{
Attitudes towards abortion and contraception in rural and urban Burkina Faso
}

\author{
Clémentine Rossier ${ }^{1}$
}

\begin{abstract}
Using results from the ethnographic literature and two qualitative studies on people's representations of different means of birth control (abstinence, contraception, abortion) in two populations in Burkina Faso (one rural and one urban), we designed a multidimensional quantitative scale to measure individuals' attitudes towards varied means of birth control. We applied it in two representative surveys in rural and urban Burkina Faso. Relating individuals' attitudes towards birth control to their socio-demographic characteristics and to their attitudes towards other life dimensions, and applying $\mathrm{N}$. Elias' theory of the civilization process, we seek to explain why abortion is less tolerated, while more widely practiced, in the city than in the villages.
\end{abstract}

\footnotetext{
${ }^{1}$ Institut National d’Etudes Démographiques, Paris. E-mail: clementine.rossier@ined.fr
} 


\section{Introduction}

Reproductive practices in contemporary Europe are usually studied in the light of existing family planning or child care services, or in terms of economic constraints and opportunities. But policy and economic explanations are not sufficient to explain the range of reproductive practices observed across Europe. Meanings individuals attribute to sexuality and conjugality, their representations of gender roles, reproduction and parenthood also deeply shape how, when, and with whom they have sex, whether or not they use contraception, and, once pregnant, their decisions to abort or give birth.

One could expect, for instance, that today's young men and women exhibit no differences as to when and with whom they have sex for the first time, given the progress in gender equality achieved since the late 1960s. Although over this period women's sexual practices have become more similar to men's in many respects (for example concerning the average number of sexual partners), young women in France still have their first sexual encounter at an older age than young men, often with a partner they say they are in love with, while young men experience sex for the first time at a younger age, often with an occasional partner (Spira, Bajos and the ACSF team, 1993). These differences stem from the fact that sexual relations still do not represent the same thing for these two groups of individuals: women are more likely to envision sex as part of a loving relationship, while men remain more likely to separate the affective and sexual spheres, although their vision of sexuality has converged on many other points.

As this example shows, the meanings attributed by individuals to diverse behaviours are not distributed at random, nor are they innate. They are shared by groups of individuals in the same social position, and passed on to some extent from one generation to the next. This example also shows that the meanings given to sexuality and reproduction are social constructs whose content can evolve, in particular when the power balance between diverse social subgroups changes (Elias 1939, Foucault 1976, 1984, 1997): we see that men and women's representations (and practices) in the area of sexuality converge to some extent as women gain power. Finally, this example shows that belief systems do not evolve as one block: closely related human representations (and behaviours) can change at different speeds, and may sometimes become contradictory. For example, these young French men, whose perception and practice of sexuality remain more instrumental than that of women, believe at the same time in the value of women's work. Moreover, social groups are open to the influence of other societies they are in contact with, creating yet another source of diversity in belief systems. Confronted at one point in time with different and sometimes conflicting representations on the same topic, individuals can choose those which best fit their 
interest of the moment (Hammel 1990); the link between representations and practices is thus often less than straightforward.

Most quantitative surveys on European reproduction (i.e. the Family and Fertility Surveys, the Gender and Generation Program) include some measures of individual representations on this topic (attitudinal questions), but these data remain under-utilized to date. This paper, which forms part of the Demographic Research Special Collection on Anthropological Demography in Europe, aims to encourage the development and use of such attitudinal variables in quantitative studies of reproduction in Europe. We do not advocate that standard attitudinal questions should be plugged into reproductive surveys, and then routinely introduced into regression models alongside more conventional socio-demographic indicators. On the contrary, in our view, the use of quantitative attitudinal variables is a very promising means to understand reproductive behaviours, but only when a number of conditions are met:

1. When data collection tools are adapted to the state of social change and to local specificities, while remaining comparable across countries;

2. When representations and practices are apprehended as part of multidimensional meaning systems;

3. When existing sociological or anthropological theories underpin the interpretation of attitudinal data.

In our view, the use of mixed-methods research protocols is the most appropriate way for demographers to meet these three conditions when studying the link between values and reproductive practices. This article shows how two preliminary qualitative studies (and a review of the existing ethnographic literature) provided us with detailed and up-to-date knowledge of individuals' representations and practice of induced abortion in two contrasting study sites. These preliminary qualitative studies also helped us to identify other meanings and behaviours closely related to the topic of study: we understood that we could not study abortion without studying contraception and abstinence at the same time, and that individuals' perceptions of early life and of gender relations was closely related to the meanings they attribute to these different birth control means (section 2). We used these qualitative results to design a different (yet comparable) survey questionnaire for each study setting, in order to capture individuals' representations and practices of these three birth control methods, apprehended in their larger universe of meanings (section 3). The analysis of these data confirmed the existence of large differences in attitudes and use of varied birth control means between the two settings, and revealed complex relations between the various parts of individuals' meaning systems and their birth control practices (section 4). Finally, we used the sociological theories of N. Elias (1939) and M. Foucault (1976, 
1984, 1997) to interpret these quantitative results. The differences in birth control meanings and practices observed between the two settings, as contradictory as they first seem, can be related to a process universally associated with increases in the division of labour and in social mobility (observed in Europe from the $16^{\text {th }}$ century and at other historical times in other cultural contexts), whereby individuals internalize the social control over their sexuality and other bodily functions in reaction to becoming closer to members of other social classes.

The type of mixed-method designs we champion is more common in research in non-Western settings, because the obvious otherness of these unknown social worlds have led Western researchers to turn earlier to combined qualitative and quantitative methodologies. The present study was conducted in West Africa, more precisely in one rural and one urban site in Burkina Faso, but we believe the methodological lessons that can be drawn from it are valid for studies of European reproduction as well.

\section{Two preliminary qualitative investigations}

\subsection{Methods and data}

The first qualitative study was conducted by the author during a five month stay in 2000 in a village in Burkina Faso about $25 \mathrm{~km}$ from the capital, Ouagadougou. Three bodies of data were constituted with the help of research assistants: 1) a series of taped and transcribed semi-structured individual interviews with ten respondents, about their representations of induced abortion, contraception, and reproduction; 2) open ended interviews with 13 informants and reproductive health professionals about abortion cases that happened in the village, abortion methods, and abortion practitioners; these interviews were recorded in notes; 3) ethnographic notes taken throughout the author's stay in the village. Thematic content analysis techniques were applied to analyze the interviews, yielding a description of the process to obtain clandestine abortions, and a description of the array of meanings attributed to birth control and reproduction in the village. The numerous anecdotes on abortion contained in the ethnographic notes were organized using existing sociological theories of secret. For a more detailed description of this fieldwork and its results, see Rossier (2002) and Rossier (2006, 2007).

The urban qualitative study was conducted in 2001 by a colleague, Abdoulaye Ouédraogo, at the Unité d'Enseignement et de Recherche en Démographie of the University of Ouagadougou, with the help of research assistants, in the capital of Burkina Faso, Ouagadougou. The team conducted 17 individual interviews in two contrasted neighbourhoods of the city (one central zoned neighbourhood, one peripheral neighbourhood) with leaders of the animist religion (2), Muslim leaders (3), Catholic 
leaders (3), Protestant leaders (3), high school teachers (2), a spokesperson of the Ministry of Education (1), leaders of women's and family planning associations (3), as well as 14 focus-groups with members of the animist religion (2), Muslims (2), Catholics (2), Protestants (2), high school students (2), out-of-school youth (2), and members of family planning associations (2). The interview guides solicited the respondents' views of reproduction and birth control; interviews were taped and transcribed. Thematic content analysis techniques were applied to these data, which yielded a description of the array of meanings attributed to birth control and reproduction in the city. For a more detailed description of this fieldwork and its results see Guiella, Ouedraogo and Rossier (2003). In addition to this formal body of data, the author collected informal knowledge on reproduction in the urban context during 9 stays in the capital between 2000 and 2006 (these stays cover a total period of 17 months, maximum continuous stay: 5 months).

\subsection{Meanings and practices of different modes of birth control in rural Burkina Faso}

Our qualitative investigation in the village only confirmed what we knew from a review of the ethnographic literature on reproductive practices and meanings in rural Africa. In our study village, like in the rest of rural Africa, fertility is high (5.9 children on average in 2000, Rossier 2002). High fertility remains valued there (Poirier and Guiella 1996): women's main role is to give children to their husband's family. Marriage is universal, and female re-marriages are almost systematic, facilitated by the prevalence of polygamy. Women stop reproducing only when they become grandmothers (Ouedraogo and Ouedraogo 1997). Although they want as many children as possible, individuals closely regulate their fertility. Switching from abstinence to sexual activity, and then back from sexual activity to abstinence, is women's main mode of fertility regulation in this context. The first of these switches corresponds to women's entry into sexuality. In the study village, like in other Mossi villages (the largest ethnic group in Burkina Faso), young girls are supposed to avoid premarital pregnancies, and get married soon after puberty (Ouedraogo and Ouedraogo 1997). After marrying and having a first child, married women aim at spacing their pregnancies to increase each child's chances of survival and their own chances of having many children. Women manage long birth intervals by breastfeeding their child for about two years and abstaining from sexual intercourse for about the same period (Page and Lesthaeghe 1981). In a study of a Mossi population in rural Burkina Faso at the end of the 1970s, Bonnet (1988) showed that women abstained from sexual intercourse for 22 months after each birth. 
Altogether, local fertility regulation goals (no births outside marriage, spaced pregnancies, and as many births as possible) are achieved by a social control over women's sexuality and marriage. Pregnancies that happen in circumstances when women were not supposed to have sexual relations (mainly in premarital and post partum situations) are seen as "shameful". Though the term "unwanted pregnancy" does not exist in the local languages of West Africa, the notion of "shameful pregnancy" is widespread. Induced abortions are one way of dealing with such "shameful" pregnancies. Abortion is perceived as "shameful" itself, since it reveals, while seeking to hide, the existence of improper pregnancies (Bleek 1981, Johnson-Hanks 2002). Though local representations severely condemn abortion as shameful, they also allow a certain freedom of interpretation: pregnancy terminations are tolerated in private, once (reproved of) sexual relations have led to an illegitimate pregnancy. Abortions become a way of "avoiding shame » (Bleek 1981), of preventing an illegitimate pregnancy from being revealed by a shameful birth; abortion is "the lesser shame " (JohnsonHanks 2002). This relative tolerance towards abortion is also facilitated by the fact that in local perceptions of reproduction, life is seen as starting rather late in the pregnancy (Renne 1996). Besides, life and death are seen as cyclical in traditional African societies: a birth is the passage of a spirit from the world of the dead to the world of the living; the spirit goes back to the other world when a person dies, and will return to the world of living with the birth of another person (Bonnet 1994, Bruyer 1997). Our own qualitative investigation (Rossier 2002) showed that in this vision of life and death, an abortion is an act that sends back to the other world a spirit who wanted to return ; an abortion does not prevent him or her from coming back some other time, in another pregnancy. Abortion is thus not seen as a final solution, as a murder. Altogether, although induced abortion plays an important role in pre-transitional societies, since it provides a necessary means to circumvent the strict rules on women's sexuality, its practice remains relatively limited in an international perspective ${ }^{2}$. Our quantitative survey estimated that there were 12 abortions per 1000 women of reproductive age in the village in 2000 (Rossier 2002), a level confirmed by another study: Henshaw et al. (1998) found that there were from 10 to 13 abortions for 1000 women of reproductive age in the rural regions of North Nigeria.

Modern contraception was introduced in Burkina Faso in the late 1980s. Despite many promotional campaigns and their availability at a subsidized price at all levels of the public health care system, the use of modern birth control methods is still relatively limited in the rural areas of the country. In our study village, only $6.6 \%$ of all women who ever had sex were currently using modern contraception at the date of our survey in 2000 (Rossier 2002), although this village had been the site of an experimental

${ }^{2}$ A "low" yearly abortion rate of about 10 abortions per 1000 women of reproductive age still means that about one woman in four will have an abortion in her life in the absence of repeat abortion. 
community-distribution family planning program in 1996-1998 (Baya et al. 1998). How do people feel about this new mode of birth control? Our qualitative study showed general support for the use of contraception for spacing, but individuals were less enthusiastic about giving contraception to women who do not have a socially accepted sexual life (pre-marital and extra-marital relationships); besides, fertility limitation was still rarely an ideal: birth limitation could only be desirable for poor individuals (Ouedraogo and Ouedraogo 1997). Using contraception means planning to have sexual intercourse and wanting to avoid a pregnancy. In societies where sexual intercourse is planned only when the arrival of a child is socially accepted and conjugally desired, and where a large number of children is desired, contraception is understandably pointless in most cases, even when well accepted (Pictet and Ouedraogo 1999). Why use contraception to control fertility, when much more respectability can be achieved by abstaining for extended periods of time?

\subsection{Meanings and practice of different modes of birth control in urban Burkina Faso}

Our qualitative investigation in the capital, where a fertility decline is currently under way (TFR = 3.1 children per woman according to the 2003 DHS, INSD 2004), revealed that birth control practices and representations are very different in the urban context. The West African urban reproductive context has rarely been documented so far, except via the DHS surveys. Pre-marital sex is far more frequent in Ouagadougou than in rural Burkina Faso. While there is a 1.4 years difference between the median age at first sexual intercourse and the median age at marriage in Ouagadougou in 2003, women's median age at first sex still corresponds to their median age at marriage in rural areas (INSD 2004). Our qualitative results show that premarital abstinence, an ideal still shared by most adults in the city, seems difficult to achieve as arranged and early marriages have become rare. Young people want to marry for love, and premarital sexuality is a way to discover and hold on to stable partners in a competitive marriage market. Young people, especially young men, also want to discover the thrills of sexual pleasure they hear about from their peers and the media, and young women sometimes use their body to get ahead in an economically harsh environment. To find a compromise between these new motives for having sex and the prevailing ideals of premarital abstinence, young people often have clandestine sexual relations, or have sex only with a future marriage partner, or with a partner they (think they) love, or distinguish between easy women (one has sex with) and future wives (with whom to abstain if possible). Once married, African city dwellers also abstain for a shorter time than their rural counterparts after each birth (Kirk and Pillet 1998). Our qualitative 
study shows that premarital abstinence is hardly valued in Ouagadougou anymore; on the contrary, marriage being now (ideally) based on love, continuous access to sexuality (within marriage) seems important to most people as a means to promote conjugal happiness.

The recourse to modern and natural contraception is widespread in Ouagadougou (29.5\% of women currently use modern contraception according to the 2003 DHS; $39 \%$ of women had sex in the last month). Contraception is used mainly by married women for limiting and for spacing. Our qualitative investigation shows that city dwellers overwhelmingly defend the idea of fertility limitation. They want to invest in the education of their children, because diplomas pave the road to employment, financial security, and social promotion. Since seeing to one child's education is expensive, most people want to limit their number of children to two or three. However, marriage and parenthood remain valued by both men and women as the obligatory passage to adulthood; women, in particular, have no social status outside marriage. Both men and women are thus very anxious to avoid celibacy and childlessness. The frequent use of natural contraceptive methods and condoms, by both married and unmarried couples who have not yet reached their desired number of children, could be linked to this fear of infertility. The level of contraceptive use is lower for non-married couples. Our qualitative investigation in Ouagadougou shows that sexual education is almost nonexistent in Ouagadougou, especially for girls, doubtless due to the stigmatization of premarital sex, which still prevails. First sexual intercourse is often unprotected, because the partners (especially the girl) are too ignorant to avoid risk. Young people, and especially girls, may also avoid protection in the hope that a pregnancy will precipitate a marital union with a desirable partner. When non-married couples do use contraception, they rarely use medical contraception. They use condoms early in relationships, to protect themselves against AIDS (vigorous condom promotion campaigns have been conducted in the city over the last decade), or natural methods (especially periodic abstinence). Young people are reluctant to reveal their sexual activity by visiting family planning services to get medical contraception.

The induced abortion rate seems to be relatively high in the cities of West Africa today. A number of studies, using different estimation methods, converge on that point. Henshaw et al. (1998) estimate that there are between 32 to 46 abortions per 1000 women aged 15-44 in the urban Southern regions of Nigeria. In Lomé in 2002, 25\% of women who already had sexual intercourse reported having had at least one abortion (Beguy et Ametepe 2004). Similarly, about one third of the interviewed women in Abidjan in 1998, 1997 and 1996 declared having had an abortion (Guillaume, 2003, Desgrées du Loû et al. 1999). We estimated that there are 40 abortions per 1000 women aged 15-49 each year in Ouagadougou (Rossier et al. 2006). Induced abortions seem to concern young, unmarried people disproportionately. In Abidjan, Guillaume and 
Desgrées du Lou (2002) conclude from their data that abortions are mainly used to delay women's first birth. In Lomé in 2002, the estimated abortion risk is 20 times higher for single women than for married ones (Beguy et Ametepe, 2004). In Ouagadougou in 2001, the abortion rate is 10 times higher for teenagers than for women over 40 (Rossier et al. 2006). Not only is the level of induced abortion much higher in the cities of West Africa than in its rural areas, but the timing and reasons of abortion seems to be different. An anthropological study in a small town in Nigeria covering two decades showed that although induced abortion appeared to be used in the 1970s mainly to avoid the shame of too closely spaced pregnancies (the shame of breaking the postpartum abstinence taboo), in the 1990s, it mainly concerned women with a premarital pregnancy (Renne 1997). Our qualitative study showed that induced abortion is severely condemned in the city in most of the social groups studied. Representations of abortion seem more negative in the city than in rural areas. An important reason for this shift seems to lie in a different perception of the beginning of life: city dwellers seem to have adopted an individualistic representation of life, where each life is unique, starts right after fertilization, and ends with death: induced abortion has become a murder. At the same time, the inhabitants of Ouagadougou often have a more equal representation of gender roles than the Mossi living in the villages next to the capital, where a patriarchal form of social organization prevails; our qualitative results show that the rare individuals who are more tolerant of abortion in the city also value gender equity.

\section{Constructing quantitative attitudinal scales on birth control}

How can we translate these qualitative results on the meanings of different birth control methods into quantitative measures, that we can relate to other attitudes, to individuals' social position, and (at the aggregate level) to their actual birth control behaviour? In this section, we explain how we constructed a survey questionnaire to measure individuals' attitudes towards contraception, abortion and abstinence and other related life domains appropriate to the rural and urban context of Burkina Faso. We then describe the rural and the urban Burkinabe samples to which we applied this questionnaire. The surveys were conducted in 2000 in nine villages $(n=1505)$, and in 2001 in Ouagadougou $(n=1380)$. Finally, we present the methods we used to analyse the resulting attitudinal data. 


\subsection{Designing the data collection tools}

To measure attitudes toward abortion, Western surveys generally ask several questions to test under which conditions the respondent views abortion as an acceptable act (Cook and Wilcox 1993). The different conditions are supposed to form a gradation. 'Physical' circumstances that can legitimize an abortion (such the health of the mother being endangered by the pregnancy, or the foetus presenting an anomaly) are distinguished from 'social' circumstances, such as the father's absence, unfavourable economic conditions, or an already numerous progeny (Benin 1985). The latter reasons are, in principle, less readily accepted by respondents. The extreme positions are held on the conservative side by people opposing abortion regardless of circumstances, and on the liberal side, by people accepting abortion regardless of circumstances. Shades of acceptance are captured by adding the number of reasons to which individuals agree. These indicators of tolerance towards abortion can then be related to socio-demographic characteristics, and, in more sophisticated studies, to other dimensions of individuals' meaning systems.

Acceptance of abortion is thus measured in surveys for different scenarios in which a woman may need to terminate her pregnancy or control her fertility, providing a complex picture of attitudes towards abortion. We decided to collect our respondents' ideas on abortion using this methodology, and to apply the same method to grasp ideas on modern contraception. We therefore also asked questions about the acceptability of contraceptive use in different situations where a woman may need to control her fertility.

However, since situations demanding fertility control are different in Burkina Faso compared to Western countries, and in rural compared to urban Burkina Faso, as was shown in section 2, we needed to adapt this methodology to the sub-Saharan context. Drawing from our qualitative results, we identified four situations in which fertility control may be required in rural Burkina Faso: not wanting more children (limiting), wanting to space children, being unmarried and having sex, having an adulterous relationship (Table 1). Based on our qualitative results, we identified an additional situation which may require birth control in the city: when a woman wants to pursue her professional activity. However, we did not distinguish in the city between spacing and limiting (both reasons being widely accepted in the city as opposed to the villages) and grouped these two categories into a single category: the married couple does not have sufficient resources to have more children at that time. Conversely, given the high prevalence of premarital sexuality in the city and its varied forms, we split the single "being unmarried and having sex" situation (in the rural survey) into two situations in the urban survey: unmarried couples who want to marry but cannot at the moment, and unmarried couples who are not thinking seriously about marriage. For each of these situations, we asked whether contraception and abortion were acceptable. We added a 
question in both surveys to know whether abortion was acceptable if the pregnancy endangered women's health, since it is a situation in which abortion is allowed in Burkina Faso.

\section{Table 1: Phrasing of different attitudinal questions on abortion and contraception}

\begin{tabular}{|c|c|c|c|}
\hline Rural sample & & Urban sample & \\
\hline Contraception & Abortion & Contraception & Abortion \\
\hline $\begin{array}{l}\text { Some people say that: } \\
\text { Contraception is good for } \\
\text { women who do not want } \\
\text { to give birth anymore. } \\
\text { Do you agree or do you } \\
\text { disagree? }\end{array}$ & $\begin{array}{l}\text { Some people say } \\
\text { that: } \\
\text { Calling the periods } \\
\text { (i.e. abortion) can be } \\
\text { justified for a woman } \\
\text { whose pregnancy } \\
\text { makes her suffer. Do } \\
\text { you agree or do you } \\
\text { disagree? }\end{array}$ & $\begin{array}{l}\text { Some people say that } \\
\text { modern contraception } \\
\text { is good when the } \\
\text { health of a married } \\
\text { woman requires it. } \\
\text { Do you agree or do } \\
\text { you disagree? }\end{array}$ & $\begin{array}{l}\text { Some people say that } \\
\text { an abortion can be } \\
\text { justified when the } \\
\text { pregnancy endangers } \\
\text { the woman's health. } \\
\text { Do you agree or do } \\
\text { yo u disagree? }\end{array}$ \\
\hline $\begin{array}{l}\text { Some people say that: } \\
\text { Contraception is good for } \\
\text { women whose children } \\
\text { are not yet awake (i.e. } \\
\text { still very small) and who } \\
\text { want to rest. } \\
\text { Do you agree or do you } \\
\text { disagree? }\end{array}$ & $\begin{array}{l}\text { Some people say } \\
\text { that: } \\
\text { Calling the periods } \\
\text { can be justified for a } \\
\text { woman whose child } \\
\text { whom she holds in } \\
\text { her arms is still small. } \\
\text { Do you agree or do } \\
\text { you disagree? }\end{array}$ & $\begin{array}{l}\text { Some people say that } \\
\text { modern contraception } \\
\text { is good when a married } \\
\text { couple does not have } \\
\text { the means to have one } \\
\text { more child at that time. } \\
\text { Do you agree or do } \\
\text { you disagree? }\end{array}$ & $\begin{array}{l}\text { Some people say that } \\
\text { an abortion can be } \\
\text { the only solution for a } \\
\text { married couple who } \\
\text { does not have the } \\
\text { means to have one } \\
\text { more child at this } \\
\text { time. } \\
\text { Do you agree or do } \\
\text { you disagree? }\end{array}$ \\
\hline $\begin{array}{l}\text { Some people say that: } \\
\text { Contraception is good for } \\
\text { young girls who know } \\
\text { they cannot control } \\
\text { themselves. } \\
\text { Do you agree or do you } \\
\text { disagree? }\end{array}$ & $\begin{array}{l}\text { Some people say } \\
\text { that: } \\
\text { Calling the periods } \\
\text { can be justified if for } \\
\text { example one could } \\
\text { not prevent a girl from } \\
\text { wandering. } \\
\text { Do you agree or do } \\
\text { you disagree? }\end{array}$ & $\begin{array}{l}\text { Some people say that } \\
\text { modern contraception } \\
\text { is good for unmarried } \\
\text { couples who think they } \\
\text { will marry one day, } \\
\text { where the young man } \\
\text { for example does not } \\
\text { have enough means. } \\
\text { Do you agree or do } \\
\text { you disagree? }\end{array}$ & $\begin{array}{l}\text { Some people say that } \\
\text { an abortion can be } \\
\text { the only solution } \\
\text { when a couple is not } \\
\text { married, they have a } \\
\text { stable relation but the } \\
\text { young man for } \\
\text { example does not } \\
\text { have enough means. } \\
\text { Do you agree or do } \\
\text { you disagree? }\end{array}$ \\
\hline
\end{tabular}


Table 1: (continued)

\begin{tabular}{|c|c|c|c|}
\hline \multicolumn{2}{|l|}{ Rural sample } & \multicolumn{2}{|l|}{ Urban sample } \\
\hline Contraception & Abortion & Contraception & Abortion \\
\hline & $\begin{array}{l}\text { Some people say } \\
\text { that: } \\
\text { Calling the periods } \\
\text { can be justified when } \\
\text { a woman took a } \\
\text { pregnancy which was } \\
\text { not that of her } \\
\text { husband. } \\
\text { Do you agree or do } \\
\text { you disagree? }\end{array}$ & $\begin{array}{l}\text { Some people say that } \\
\text { modern contraception } \\
\text { is good for unmarried } \\
\text { couples, but who are } \\
\text { not ready to commit, } \\
\text { for example if one of } \\
\text { the two is not serious. } \\
\text { Do you agree or do } \\
\text { you disagree? }\end{array}$ & $\begin{array}{l}\text { Some people say that } \\
\text { an abortion can be } \\
\text { the only solution for a } \\
\text { couple who is not } \\
\text { married and is not } \\
\text { ready to commit, for } \\
\text { example if one of the } \\
\text { two is not serious: } \\
\text { Do you agree or do } \\
\text { you disagree? }\end{array}$ \\
\hline & & $\begin{array}{l}\text { Some people say that } \\
\text { modern contraception } \\
\text { is good to allow a } \\
\text { married woman to } \\
\text { pursue her (economic) } \\
\text { activities. } \\
\text { Do you agree or do } \\
\text { you disagree? }\end{array}$ & $\begin{array}{l}\text { Some people say that } \\
\text { abortion can be the } \\
\text { only solution for a } \\
\text { married woman who } \\
\text { wants to pursue her } \\
\text { (economic) activities. } \\
\text { Do you agree or do } \\
\text { you disagree? }\end{array}$ \\
\hline & & & $\begin{array}{l}\text { Some people say that } \\
\text { abortion can be the } \\
\text { only solution in case } \\
\text { of adultery, for } \\
\text { example when a } \\
\text { married man makes a } \\
\text { young girl pregnant or } \\
\text { when a woman } \\
\text { becomes pregnant by } \\
\text { a young man. } \\
\text { Do you agree or do } \\
\text { you disagree? }\end{array}$ \\
\hline
\end{tabular}


Note that we did not ask the questions pertaining to the same fertility control situation in exactly the same terms for contraception and abortion. Also, we asked if contraception was acceptable in some birth control situations and if abortion was acceptable in a different set of situations. We also worded the questions somewhat differently in the city and in the rural surveys. These limitations are due to the experimental nature of this research, and could easily be remedied in future applications. We explain below how we managed to work with a set of comparable questions despite these limitations.

One methodological innovation in this work is that we applied the type of approval scale used in abortion research in Western settings to measure tolerance towards contraception. In the DHS surveys, individuals are merely asked if they approve of contraception. Here, we defined different situations in which contraception could be seen as more or less acceptable.

Research on attitudes towards abortion in Western countries usually relates individuals' acceptability of abortion to their socio-demographic characteristics, and to their attitudes in other life domains: their vision of life and death (how acceptable they think death penalty or euthanasia is, for example), their perception of the acceptability of government involvement in private decisions, their perception of gender relations, their conformity in terms of family values (for instance if they think divorce is acceptable) (for a review of this literature, see Rossier 2005). Using the results of our qualitative study in rural Burkina Faso, which were backed up on all points by the existing ethnographic literature, we identified three areas of life whose meanings seemed closely related to individuals' representations of birth control in that context: people's vision of life and death, their perception of sexuality, and the extent to which they think they are in charge of their own reproductive decisions (as opposed to God). We designed three questions to capture individuals' attitudes on each of these three dimensions, using our qualitative results to decide on the phrasing (Table 2). For example, the question "An old man who dies will come back one day in a child of his lineage. Do you agree or not?” refers to the cyclical vision of life and death which was described above; this question would not be applicable in a Western context (where a qualitative study may reveal instead that visions of life and death are more appropriately apprehended by questions on euthanasia and suicide).

We did not design corresponding questions for the city survey. Our preliminary qualitative results need to be validated by other studies before possibly being transformed into quantitative questions. We should also point out that we did not include attitudes towards gender relations as a structuring dimension of attitudes towards abortion in the rural sample, although we knew from existing Western studies that they shape perceptions of abortion (Rossier 2005). The rural qualitative investigation did not reveal its importance to us because there was absolutely no 
variation in terms of gender attitudes and practices in that setting (Ouedraogo 2000); the Ouagadougou qualitative study revealed much more variation on this dimension. Attitudes towards gender relations should be included in future studies of attitudes towards birth control in the African context.

Table 2: $\quad$ Phrasing of different attitudes questions on abstinence, fertility limitation, and life and death

\begin{tabular}{|c|c|c|}
\hline \multicolumn{3}{|l|}{ Rural } \\
\hline Abstinence & $\begin{array}{l}\text { Role of God in fertility } \\
\text { decisions }\end{array}$ & Life and death \\
\hline $\begin{array}{l}\text { Some people say that: } \\
\text { Nowadays, it is difficult for } \\
\text { most young people to } \\
\text { abstain. } \\
\text { Do you agree or do you } \\
\text { disagree? }\end{array}$ & $\begin{array}{l}\text { Some people say that: } \\
\text { A woman who takes drugs } \\
\text { (contraception) will not have the } \\
\text { number of children that God } \\
\text { chose for her. } \\
\text { Do you agree or do you } \\
\text { disagree? }\end{array}$ & $\begin{array}{l}\text { Some people say that: } \\
\text { When a little child dies, it is } \\
\text { sad, but some say it will come } \\
\text { back. } \\
\text { Do you agree or do you } \\
\text { disagree? }\end{array}$ \\
\hline $\begin{array}{l}\text { Some people say that: } \\
\text { Nowadays, it is difficult for a } \\
\text { woman and her husband to } \\
\text { control themselves after the } \\
\text { birth of a child. } \\
\text { Do you agree or do you } \\
\text { disagree? }\end{array}$ & $\begin{array}{l}\text { Some people say that: } \\
\text { The spirits of the children who } \\
\text { cannot come will take revenge } \\
\text { on the woman who takes drugs } \\
\text { (contraception). } \\
\text { Do you agree or do you } \\
\text { disagree? }\end{array}$ & $\begin{array}{l}\text { Some people say that: } \\
\text { An old man who dies will come } \\
\text { back one day in a child of the } \\
\text { lineage. } \\
\text { Do you agree or do you } \\
\text { disagree? }\end{array}$ \\
\hline $\begin{array}{l}\text { Some people say that: } \\
\text { A young girl who becomes } \\
\text { pregnant while still with her } \\
\text { parents nowadays, it is not } \\
\text { really a shame anymore } \\
\text { because it is common. } \\
\text { Do you agree or do you } \\
\text { disagree? }\end{array}$ & $\begin{array}{l}\text { Some people say that: } \\
\text { The number of children is not } \\
\text { decided by God, but by the } \\
\text { husband and his wife or the } \\
\text { family. } \\
\text { Do you agree or do you } \\
\text { disagree? }\end{array}$ & $\begin{array}{l}\text { Some people say that: } \\
\text { A belly which goes bad } \\
\text { (spontaneous abortion), is not } \\
\text { important, it is a pregnancy } \\
\text { which will come back. } \\
\text { Do you agree or do you } \\
\text { disagree? }\end{array}$ \\
\hline
\end{tabular}




\subsection{The rural and urban samples}

Our rural study site was a health district of nine villages close to the capital (the village of the qualitative study and eight surrounding villages). Its total population was 7,498 at the same time of the survey, of which 1,554 women of reproductive age. The sampling strategy entailed one level of cluster. Compounds were chosen at random (using a list of compounds established in 1995), and in each selected compound, all women aged 15-49 and one randomly chosen man aged 18 or above were selected. This sampling strategy means that the results are representative of women in average compounds, and not of average women in the study site. We interviewed a sample of 1,055 women aged 15-49 (a sampling rate of $67.9 \%$, with a response rate of $100 \%$ ) and 450 men. Weights were calculated to combine men and women, so that together, these data are representative of men and women of reproductive age living in an average compound in these nine villages (for more details, see Rossier 2002).

We administered the urban questionnaire to a representative sample of men and women living in Ouagadougou in November 2001.We adopted a two-stage cluster sampling procedure. Using city-wide data from the 1996 census, updated for non-zoned areas, we randomly drew 57 census tracks weighted by their population. We then enumerated the population in the selected census tracks, and randomly drew households weighted by their size. All women aged 15-49 were interviewed in the selected households. A separate sample of households was constituted for the sample of males (aged 15 and above); 82\% of the selected men and $84 \%$ of the selected women completed the questionnaire. Altogether, 963 women aged 15-49 and 417 men aged 15 and above were interviewed. Weights were calculated for each individual, to render the two samples representative of women and men of reproductive age in Ouagadougou (for more details, see Guiella, Ouedraogo and Rossier 2003).

\subsection{Analyzing attitudinal data}

We analyse these attitudinal data as follows, according to standards developed in research on attitudes towards abortion in Western settings. We first describe the respondents' approbation of abortion and contraception in different situations, and order the situations according to how much approbation they foster. An analysis of this order shows whether people think differently about abortion and contraception for situations of illegitimate sexuality, and if these differences are the same in the urban and rural samples. We verify that this order at the aggregate level is also the logical gradient used by individuals separately. We then construct a single indicator of tolerance towards abortion and contraception for both samples, adding the number of reasons for which 
abortion and contraception are tolerated, restricting the comparison to those items which are more directly comparable. We are then able to compare more rigorously the general levels of tolerance between the two settings, and between men and women.

We then perform a series of linear regressions of diverse socio-demographic variables (religious affiliation, sex, education, age, proxy of poverty /affluence level, marital status, migratory status, ethnicity) on individuals' degree of tolerance towards abortion and contraception in each sample. In both samples, a proxy of poverty level (Kobiane and Soura 2003) was constructed from variables indicating the possession by the household of varied goods; the household goods considered were not the same in the city (television, VCR, telephone, refrigerator, transportation means) and in the villages (radio, plough, cart, transportation means, draft animal, breeding animal). In both cases, a principal component analysis was performed on the selected variables, and the factorial scores, with one more mathematical transformation, yield an indicator of poverty / wealth for each individual; this indicator was divided into five equal classes in the urban sample, four equal classes in the rural sample, so as to give the quartile or quintile of poverty / wealth in each sample.

We finally relate individuals' scores on the scale of tolerance towards abortion and contraception in another series of linear regressions and, using the rural sample only, attitudes towards abstinence, towards life and death, and the role of God in fertility decisions. Tolerance scales were built for each of these dimensions by adding the responses to the three questions on each dimension.

\section{Results}

As we can see (Table 3), about two thirds of our rural respondents think the use of contraception is acceptable to limit births or for unmarried couples, and about one quarter disagree: the agreement is more pronounced (80\%) when contraception is intended to replace post-partum abstinence. Although contraception is well accepted in our rural survey overall, the idea of limiting one's number of births and having sex outside marriage, and the use of contraception in both these situations, still meets a fair degree of opposition in the population.

Urban respondents, just like rural respondents, agree in their majority that using contraception is acceptable: their acceptance is somewhat more pronounced than that of rural respondents (about three quarters of urbanites approve contraception, against two thirds of rural respondents, whatever the reason) (Table 4). Just like rural respondents, urban respondents more often disapprove of contraception for unmarried couples (a quarter of urban respondents disapprove, the same proportion as in the villages), but 
unlike rural respondents, they do not disapprove of contraception to limit the number of births.

A majority of the rural respondents disapprove of induced abortion, whatever the situation (Table 3): about $60 \%$ of the respondents find induced abortion unacceptable when the pregnant woman encounters health problems, when her last child is still small, when the couple is not married, and when the couple is adulterous, and between 25 and $30 \%$ find it acceptable for any of these reasons. Abortions in the case of "shameful" pregnancies meet a somewhat higher degree of approval, especially when the couple is not married or adulterous, but the differences are not marked.

Table 3: Attitudes towards contraception and abortion by reason for acceptance, nine villages in Burkina Faso, 2000, n= 1522.

\begin{tabular}{lllll}
\hline $\begin{array}{l}\text { It is acceptable to } \\
\text { use contraception } \\
\text { when }\end{array}$ & $\begin{array}{l}\text { The married couple } \\
\text { does not want } \\
\text { more children \% }\end{array}$ & $\begin{array}{l}\text { The last child is } \\
\text { still small \% }\end{array}$ & $\begin{array}{l}\text { The couple is } \\
\text { unmarried \% }\end{array}$ & \\
\hline Totally agrees & 53,0 & 68,0 & 51,4 & \\
Partly agrees & 11,2 & 11,6 & 12,5 & \\
Partly disagrees & 8,7 & 3,7 & 10,0 & \\
Totally disagrees & 15,2 & 8,4 & 15,2 & \\
Don't know & 11,9 & 8,3 & 10,9 & \\
N & 1497 & 1495 & 1494 & adulterous \% \\
\hline It is acceptable to & Pregnancy with & The last child is & The couple is & The couple is \\
use abortion & health problems\% & still small \% & unmarried \% & \\
when: & & & & 20,1 \\
\hline Totally agrees & 18,4 & 19,9 & 9,1 & 11,5 \\
Partly agrees & 9,5 & 10,3 & 10,9 & 44,5 \\
Partly disagrees & 9,6 & 9,3 & 46,5 & 10,8 \\
Totally disagrees & 49,4 & 49,1 & 13,5 & 1492 \\
Don't know & 13,1 & 11,5 & 1494 & \\
N & 1495 & 1494 & & \\
\hline
\end{tabular}

Source: « Stratégies Reproductives en Milieu Rural » survey, 2000, Unité d’Enseignement et de Recherche en Démographie, Université de Ouagadougou. 
Urban respondents' attitudes towards abortion vary in one way from that of their rural counterparts (Table 4). Their opposition towards abortion is stronger: for most reasons, about $90 \%$ of them disagree with abortion. Urban respondents make an exception when women's health is at stake, in which case a majority finds abortion acceptable $^{3}$. But urban respondents, like rural respondents, are somewhat more open to abortion for "shameful pregnancies" (unmarried and adulterous couples), and the difference are more pronounced than in the rural sample.

To synthesize these results, we joined the two "agree" categories together, and the two "disagree" categories together, the third modality being "Do not know" (Table 5). We also reduced the analysis to those questions on abortion and contraception that were comparable. To capture respondents' attitudes towards contraception, we kept two questions in each sample: 1) the couple is married but does not want more children now; 2) the couple is unmarried. To measure respondents' attitudes towards abortion, we kept three questions in each sample: 1) the married couple does not want a child now; 2) the couple is unmarried and does not want to get married; 3) the couple is adulterous. We ordered these reasons according to how many people disapproved of abortion in each case, in the urban and rural samples. We see that more rural respondents are unsure how to answer these questions than urban respondents, and that city residents are especially sure of themselves when they give their opinion on abortion.

\footnotetext{
${ }^{3}$ In the rural survey, the question was asked as follows: was an abortion acceptable when the pregnancy "makes the woman suffer"; in the city: "when the pregnancy endangers the woman's health"? Because of individuals' different visions of the causality of sicknesses, it did not seem to make sense to ask if an abortion was acceptable when the mother's health was endangered by the pregnancy in the rural survey, although we should have tested both questions in both surveys to have comparable data. As it stands, the "health" question is not comparable in the two surveys, and we eliminated it from further analysis.
} 
Table 4: Attitudes towards contraception and abortion by reason for acceptance, Ouagadougou, Burkina Faso, 2001, n= 1380.

\begin{tabular}{|c|c|c|c|c|c|c|}
\hline $\begin{array}{l}\text { It is } \\
\text { acceptable } \\
\text { to use } \\
\text { contracepti } \\
\text { on when }\end{array}$ & $\begin{array}{r}\text { Woman's } \\
\text { health is } \\
\text { in danger } \\
\%\end{array}$ & $\begin{array}{r}\text { The married } \\
\text { couple does } \\
\text { not want } \\
\text { more } \\
\text { children \% }\end{array}$ & $\begin{array}{r}\text { The couple } \\
\text { is unmarried } \\
\text { but want to } \\
\text { get married } \\
\%\end{array}$ & $\begin{array}{r}\text { The couple is } \\
\text { unmarried } \\
\text { and does not } \\
\text { want to get } \\
\text { married \% }\end{array}$ & $\begin{array}{r}\text { The married } \\
\text { woman } \\
\text { wants to } \\
\text { pursue her } \\
\text { activities \% }\end{array}$ & \\
\hline $\begin{array}{l}\text { Totally } \\
\text { agrees }\end{array}$ & 69,6 & 66,6 & 63,2 & 63,7 & 54,0 & \\
\hline Partly agrees & 8,0 & 9,0 & 7,4 & 6,7 & 9,9 & \\
\hline $\begin{array}{l}\text { Partly } \\
\text { disagrees }\end{array}$ & 4,7 & 5,4 & 6,5 & 5,2 & 6,7 & \\
\hline $\begin{array}{l}\text { Totally } \\
\text { disagrees }\end{array}$ & 10,2 & 13,7 & 17,7 & 19,4 & 24,5 & \\
\hline Don't know & 7,6 & 5,2 & 5,2 & 4,9 & 5,0 & \\
\hline$N$ & 1373 & 1379 & 1377 & 1376 & 1376 & \\
\hline $\begin{array}{l}\text { It is } \\
\text { acceptable } \\
\text { to use } \\
\text { abortion } \\
\text { when: }\end{array}$ & $\begin{array}{r}\text { Woman's } \\
\text { health is in } \\
\text { danger \% }\end{array}$ & $\begin{array}{r}\text { The married } \\
\text { couple does } \\
\text { not want } \\
\text { more } \\
\text { children \% }\end{array}$ & $\begin{array}{r}\text { The couple } \\
\text { is unmarried } \\
\text { but want to } \\
\text { get married } \\
\%\end{array}$ & $\begin{array}{r}\text { The couple is } \\
\text { unmarried } \\
\text { and does not } \\
\text { want to get } \\
\text { married \% }\end{array}$ & $\begin{array}{r}\text { The married } \\
\text { woman } \\
\text { wants to } \\
\text { pursue her } \\
\text { activities \% }\end{array}$ & $\begin{array}{r}\text { The } \\
\text { couple is } \\
\text { adulterous } \\
\%\end{array}$ \\
\hline $\begin{array}{l}\text { Totally } \\
\text { agrees }\end{array}$ & 49,0 & 6,1 & 5,1 & 9,3 & 2,9 & 9,9 \\
\hline Partly agrees & 5,9 & 3,4 & 3,0 & 2,9 & 1,7 & 9,1 \\
\hline $\begin{array}{l}\text { Partly } \\
\text { disagrees }\end{array}$ & 7,4 & 3,6 & 3,2 & 3,3 & 2,4 & 4,8 \\
\hline $\begin{array}{l}\text { Totally } \\
\text { disagrees }\end{array}$ & 34,3 & 85,6 & 87,3 & 82,7 & 91,7 & 72,3 \\
\hline Don't know & 3,4 & 1,3 & 1,4 & 1,8 & 1,3 & 4,0 \\
\hline$N$ & 1374 & 1374 & 1374 & 1376 & 1374 & 1362 \\
\hline
\end{tabular}

Source : Enquête Santé de la Reproduction à Ouagadougou, 2001, Unité d'Enseignement et de Recherche en Démographie, Université de Ouagadougou. 
Rossier: Attitudes towards abortion and contraception in rural and urban Burkina Faso

Table 5: Attitudes towards contraception and abortion by reason for acceptances in nine villages and in Ouagadougou, Burkina Faso, 2000 and 2001, $n=1522$ and 1380.

\begin{tabular}{|c|c|c|c|}
\hline \multicolumn{4}{|l|}{ Rural sample } \\
\hline $\begin{array}{l}\text { It is acceptable to use } \\
\text { contraception when: }\end{array}$ & $\begin{array}{l}\text { The married couple } \\
\text { does not want a child } \\
\text { now } \%\end{array}$ & $\begin{array}{l}\text { The married couple } \\
\text { does not want more } \\
\text { children } \%\end{array}$ & $\begin{array}{l}\text { The couple is unmarried } \\
\%\end{array}$ \\
\hline Disagrees & 12,1 & 23,9 & 25,2 \\
\hline Agrees & 79,6 & 64,2 & 63,9 \\
\hline Don't know & 8,3 & 11,9 & 10,9 \\
\hline $\mathrm{N}$ & 1495 & 1497 & 1494 \\
\hline $\begin{array}{l}\text { It is acceptable to use } \\
\text { abortion when: }\end{array}$ & $\begin{array}{l}\text { The couple is } \\
\text { adulterous \% }\end{array}$ & $\begin{array}{l}\text { The couple is } \\
\text { unmarried } \%\end{array}$ & $\begin{array}{l}\text { The married couple } \\
\text { does not want a child } \\
\text { now } \%\end{array}$ \\
\hline Disagrees & 56,0 & 57,3 & 58,4 \\
\hline Agrees & 33,2 & 29,2 & 30,2 \\
\hline Don't know & 10,8 & 13,5 & 11,5 \\
\hline $\mathrm{N}$ & 1492 & 1494 & 1494 \\
\hline \multicolumn{4}{|l|}{ Urban sample } \\
\hline $\begin{array}{l}\text { It is acceptable to use } \\
\text { contraception when: }\end{array}$ & $\begin{array}{l}\text { The married couple } \\
\text { does not want more } \\
\text { children now } \%\end{array}$ & $\begin{array}{l}\text { The couple is } \\
\text { unmarried but wants } \\
\text { to get married } \%\end{array}$ & $\begin{array}{l}\text { The couple is unmarried } \\
\text { and does not want to } \\
\text { get married } \%\end{array}$ \\
\hline Disagrees & 19,2 & 24,2 & 24,7 \\
\hline Agrees & 75,6 & 70,6 & 70,4 \\
\hline Don't know & 5,2 & 5,2 & 4,9 \\
\hline $\mathrm{N}$ & 1379 & 1377 & 1376 \\
\hline $\begin{array}{l}\text { It is acceptable to use } \\
\text { abortion when: }\end{array}$ & $\begin{array}{l}\text { The couple is } \\
\text { adulterous } \%\end{array}$ & $\begin{array}{l}\text { The couple is } \\
\text { unmarried } \%\end{array}$ & $\begin{array}{l}\text { The married couple } \\
\text { does not want more } \\
\text { children now } \%\end{array}$ \\
\hline Disagrees & 77,1 & 86,1 & 89,2 \\
\hline Agrees & 18,9 & 12,2 & 9,5 \\
\hline Don't know & 4,0 & 1,8 & 1,3 \\
\hline $\mathrm{N}$ & 1362 & 1376 & 1374 \\
\hline
\end{tabular}

Source : « Stratégies Reproductives en Milieu Rural » survey, 2000 and Enquête Santé de la Reproduction à Ouagadougou, 2001, Unité d'Enseignement et de Recherche en Démographie, Université de Ouagadougou 
We then verified that this order at the aggregate level is also the logical gradient used by individuals separately. For example, do those individuals who agree with the second most easily accepted reason to use contraception sample- wide also agree with the first most easily accepted reason sample-wide? Table 6 gives the proportion of respondents having "logical" opinions on contraception and abortion in each sample (in the sense that they follow the aggregate ordering when approving or disapproving of birth control use in the different situations). We see that in both samples and on both topics about 8 individuals out of 10 are "logical", except for urban individuals giving their opinion on abortion, where about 9 individuals out of 10 are "logical": there seems to be a greater consensus on this issue in the city than in the villages, and a greater consensus than for contraception. Individuals who gave "do not know" answers to at least one of the questions were excluded from the calculations of the proportion of "logical" respondents on contraception (or abortion), and from the rest of the analysis.

Table 6: Proportion of individuals, who follow the aggregate order in their acceptance of different reasons to use contraception and abortion in nine villages and in Ouagadougou, Burkina Faso, 2000 and 2001.

\begin{tabular}{lllll}
\hline & \multicolumn{3}{l}{ Contraception } & Abortion \\
\cline { 2 - 5 } & Urban & Rural & Urban & Rural \\
\hline All & 81,4 & 80,2 & 90,4 & 80,1 \\
$\mathrm{~N}$ & 1274 & 1245 & 1285 & 1196 \\
\hline
\end{tabular}

Source : « Stratégies Reproductives en Milieu Rural » survey, 2000 and Enquête Santé de la Reproduction à Ouagadougou, 2001, Unité d'Enseignement et de Recherche en Démographie, Université de Ouagadougou.

We then constructed a single indicator of tolerance towards abortion and contraception for both samples, adding the number of reasons for which abortion and contraception are tolerated, including only those individuals who have an opinion on every item, but not restricting ourselves to "logical" individuals (Table 7).

We see (Figure 1) that according to this indicator, urban respondents are slightly more approving of contraception than rural respondents, confirming our previous analysis. Villagers are slightly more likely than city dwellers to disapprove of contraception for unmarried couples. But similarities are here more striking than differences. Attitudes towards premarital abstinence seem not so different in the two settings, since in both samples, between 20 and 25\% of individuals think contraception is not acceptable for unmarried couples. Women approve of contraception more readily than men, both in the rural and urban samples. 
Rossier: Attitudes towards abortion and contraception in rural and urban Burkina Faso

Table 7: Indicator of approval of contraception and abortion in nine villages and in Ouagadougou, Burkina Faso, 2000 and 2001.

\begin{tabular}{lllllll}
\hline & Rural & & \multicolumn{3}{l}{ Urban } \\
\hline $\begin{array}{l}\text { Nb of accepted reasons } \\
\text { for using contraception }\end{array}$ & Men & Women & All & Men & Women & All \\
0 & 14.4 & 8.9 & 11.7 & 11.9 & 7.9 & 10.0 \\
1 & 31.2 & 27.4 & 29.3 & 30.9 & 20.7 & 26.1 \\
2 & 54.3 & 63.7 & 59.0 & 57.3 & 71.8 & 64.0 \\
$\mathrm{~N}$ & 381 & 864 & 1245 & 394 & 880 & 1274 \\
$\mathrm{Nb}$ of accepted reasons & & & & & & \\
for using abortion & & & & & & \\
0 & 56.8 & 40.2 & 48.4 & 78.8 & 68.3 & 73.9 \\
1 & 17.4 & 16.1 & 16.8 & 12.7 & 17.5 & 14.9 \\
2 & 13.8 & 17.7 & 15.7 & 6.1 & 9.5 & 7.7 \\
3 & 12.1 & 26.1 & 19.1 & 2.4 & 4.8 & 3.5 \\
$\mathrm{~N}$ & 363 & 833 & 1196 & 401 & 884 & 1285 \\
\hline
\end{tabular}

Source : « Stratégies Reproductives en Milieu Rural » survey, 2000 and Enquête Santé de la Reproduction à Ouagadougou, 2001, Unité d'Enseignement et de Recherche en Démographie, Université de Ouagadougou.

Figure 1: Indicator of approval of contraception in nine villages and in Ouagadougou, Burkina Faso, 2000 and 2001

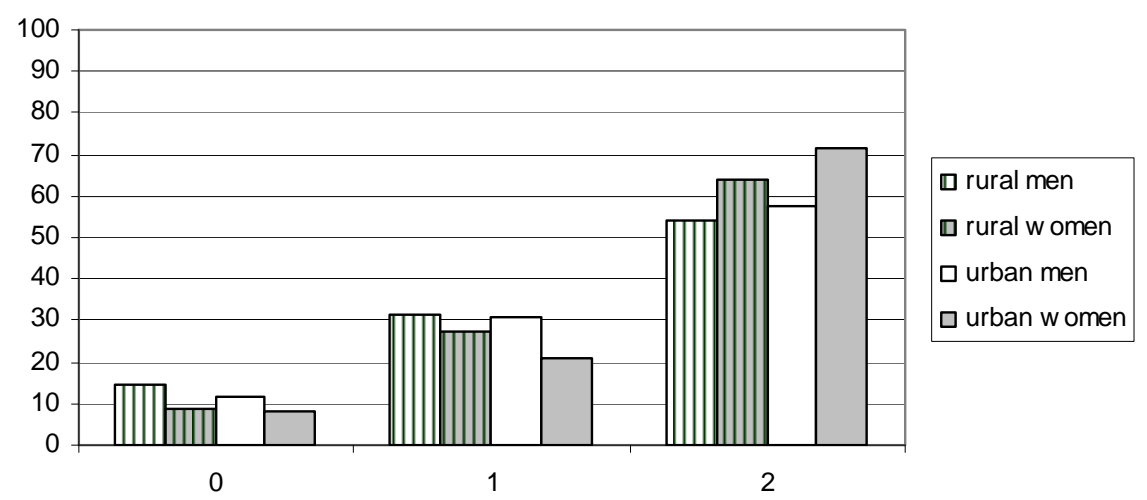

number of accepted reasons for using contraception 
Differences in opinions on abortion (Figure 2) are more pronounced between sexes and between settings compared to opinions on contraception: women are markedly more tolerant towards abortion than men in the city and in the villages, and rural respondents are much more open on this topic than urban respondents. We see that only $40 \%$ of rural women disapprove of abortion in any of the proposed situations, while $79 \%$ of urban men do not tolerate abortion under any circumstances (remember that the reason "the woman's life is in danger" is not included in this analysis).

Figure 2: Indicator of approval of abortion in nine villages and in Ouagadougou, Burkina Faso, 2000 and 2001

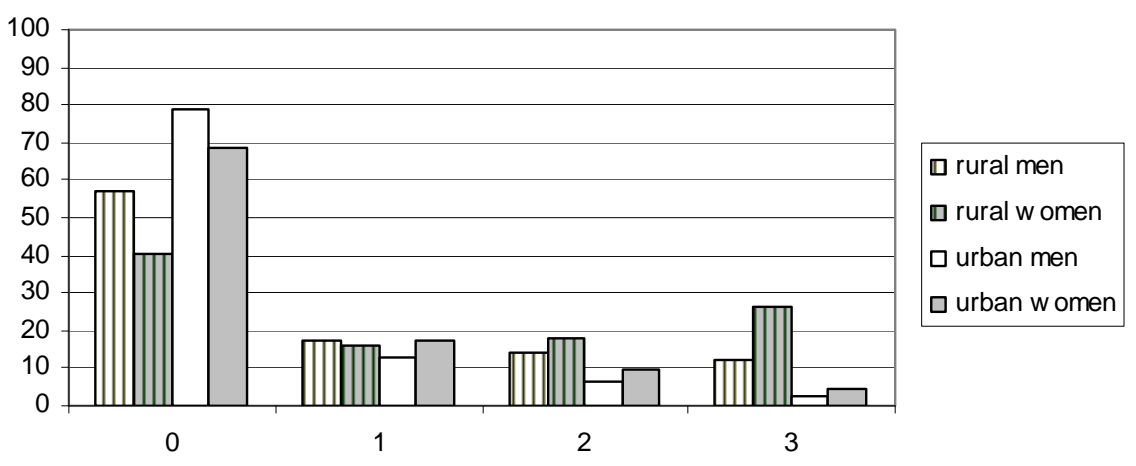

number of accepted reasons for using abortion

Most respondents who are relatively tolerant towards abortion accept just one circumstance for which they think this practice is justified: in case of pregnancies resulting from adulterous relationships. Rural women are different from all other respondents in that regard: when they are tolerant towards abortion, they are more likely to accept all the proposed reasons as acceptable, and not just one.

How is tolerance towards contraception related to individuals' specific sociodemographic characteristics? In the following multivariate analyses, we will examine all results significant at $5 \%$ or less. Villagers approve more of contraception when they are or were married, and when they have a primary education compared to no education at all (Table 8). People following the traditional religion approve less of contraception than people adhering to a revealed religion (Christians or Muslims) (this is true only for men, results by sex not shown); Muslims are more likely than Christians to approve of contraception (this is true only for women, results by sex not shown). Ethnicity, age, migration history and sex have no relation with attitudes towards contraception in the villages, once other factors are controlled for. 
Table 8: Linear regression of individuals' socio-demographic variables on their approval of contraception and abortion in nine villages, Burkina Faso, 2000, n=942.

\begin{tabular}{|c|c|c|c|c|}
\hline & Contraception & & Abortion & \\
\hline Variables & Standard estimate & $P>|T|$ & Standard estimate & $P>|T|$ \\
\hline Age & -0.03 & 0.18 & -0.01 & 0.00 \\
\hline Christian & ref. & & ref. & \\
\hline Traditional & -0.38 & 0.00 & 0.00 & 0.99 \\
\hline Muslim & 0.11 & 0.02 & -0.14 & 0.10 \\
\hline Has not lived +6 months out of BF & ref. & & ref. & \\
\hline Has lived +6 months out of BF & -0.11 & 0.06 & -0.18 & 0.08 \\
\hline Has not lived +6 months in the city & ref. & & ref. & \\
\hline Has lived +6 months in the city & -0.11 & 0.08 & -0.10 & 0.39 \\
\hline Single & ref. & & ref. & \\
\hline Married & 0.23 & 0.00 & 0.27 & 0.04 \\
\hline Div / sep / widowed & 0.24 & 0.08 & 0.07 & 0.78 \\
\hline No education & ref. & & ref. & \\
\hline Primary & 0.16 & 0.02 & -0.09 & 0.51 \\
\hline Secondary or more & -0.04 & 0.74 & -0.08 & 0.73 \\
\hline 1st quartile of poverty & ref. & & ref. & \\
\hline 2nd quartile of poverty & -0.26 & 0.15 & -0.73 & 0.03 \\
\hline 3rd quartile of poverty & -0.31 & 0.08 & -0.67 & 0.05 \\
\hline 4th quartile of poverty & -0.22 & 0.21 & -0.64 & 0.05 \\
\hline Mossi & 0.30 & 0.50 & -0.96 & 0.48 \\
\hline Peul & 0.54 & 0.35 & -0.27 & 0.87 \\
\hline Other & ref. & & ref. & \\
\hline Men & ref. & & ref. & \\
\hline Women & 0.01 & 0.87 & 0.17 & 0.09 \\
\hline
\end{tabular}

Source : « Stratégies Reproductives en Milieu Rural » survey, 2000. R-square $=0.05$

Urban respondents (Table 9), just like rural respondents, approve more of contraception when they are more educated. Being divorced or separated or widowed is related to less open attitudes towards contraception, but this is true only for men (results by sex not shown); men who do not remarry are likely to be few in number and may 
have (unknown) specific characteristics. Women are significantly more likely to approve of contraception in the city even, when other factors are controlled for, in contrast to what was observed in the villages. Age, ethnicity, religion, and migratory history bear no relationship with opinions on contraception in the urban sample.

Table 9: Linear regression of individuals' socio-demographic variables on their approval of contraception and abortion in Ouagadougou, Burkina Faso, 2001, $n=633$.

\begin{tabular}{|c|c|c|c|c|}
\hline & Contraception & & Abortion & \\
\hline Variables & Standard estimate & $P>|T|$ & Standard estimate & $P>|T|$ \\
\hline Age & -0.00 & 0.45 & -0.00 & 0.79 \\
\hline Christian & ref. & & ref. & \\
\hline Other & 0.38 & 0.08 & 1.30 & 0.00 \\
\hline Muslim & -0.03 & 0.59 & 0.15 & 0.01 \\
\hline Did not grow up in the village & ref. & & ref. & \\
\hline Grew up in the village & 0.05 & 0.33 & -0.07 & 0.26 \\
\hline Single & ref. & & ref. & \\
\hline Married & 0.03 & 0.66 & -0.13 & 0.13 \\
\hline Div / sep / widowed & -0.27 & 0.05 & -0.24 & 0.14 \\
\hline No education & ref. & & ref. & \\
\hline Primary & 0.21 & 0.00 & -0.05 & 0.56 \\
\hline Secondary & 0.16 & 0.03 & -0.02 & 0.78 \\
\hline More than secondary & 0.25 & 0.04 & 0.27 & 0.05 \\
\hline 1st quintile of poverty & ref. & & ref. & \\
\hline 2nd quintile of poverty & -0.13 & 0.09 & 0.05 & 0.56 \\
\hline 3rd quintile of poverty & 0.05 & 0.58 & 0.03 & 0.78 \\
\hline 4th quintile of poverty & 0.07 & 0.41 & 0.09 & 0.35 \\
\hline $5^{\text {th }}$ quintile of poverty & 0.02 & 0.79 & 0.24 & 0.01 \\
\hline Mossi & 0.00 & 0.96 & -0.09 & 0.19 \\
\hline Peul & 0.14 & 0.31 & -0.29 & 0.06 \\
\hline Other & ref. & & ref. & \\
\hline Men & ref. & & ref. & \\
\hline Women & 0.18 & 0.00 & 0.20 & 0.00 \\
\hline
\end{tabular}

Source : Enquête Santé de la Reproduction à Ouagadougou, 2001, Unité d'Enseignement et de Recherche en Démographie, Université de Ouagadougou.. R-square $=0.07$ 
Let us now examine the relation between socio-economic characteristics and attitudes towards abortion in both settings. We see that in the villages (Table 8) poor, younger, and married individuals are more likely to be tolerant towards abortion. Neither religion, education, migratory history, sex nor ethnicity make a difference when it comes to opinions about abortion in the rural sample.

In the urban sample, we see (Table 9) that the highly educated and the most rich are more likely to be open to abortion. Women are more tolerant as well, while Christians are significantly less likely to approve of abortion. Neither age, marital status, migratory history nor ethnicity make a difference in attitudes towards abortion.

How are attitudes towards abortion and contraception linked to attitudes in other areas of life (in the rural sample only)? As we can see (Table 10), people who disapprove of contraception are more likely to approve of abstinence. The role of God in reproductive decisions (versus the role of individuals) is not related to ideas about contraception in our rural sample.

\section{Table 10: Linear regressions of individuals' attitudes towards abstinence, role of God in fertility decisions, and life and death, on their approval of contraception and abortion in nine villages, Burkina Faso, 2000.}

\begin{tabular}{lllll}
\hline \multirow{2}{*}{ Variables } & Contraception & \multicolumn{3}{l}{ Abortion } \\
\cline { 2 - 5 } & Standard estimate & $\mathrm{P}>|\mathrm{T}|$ & Standard estimate & $\mathrm{P}>|\mathrm{T}|$ \\
\hline Abstinence & 0.16 & 0.00 & 0.16 & 0.00 \\
Role of God & -0.03 & 0.28 & 0.16 & 0.00 \\
Life and death & -0.01 & 0.64 & 0.14 & 0.00 \\
$\mathrm{n}$ & 1227 & & 1185 & \\
\hline
\end{tabular}

Source : « Stratégies Reproductives en Milieu Rural » survey, 2000.

Note : a higher score on the "abstinence" variable means that people are less strict about abstinence. A higher score on the "fertility limitation" variable means that people attribute a greater importance to God deciding the number of births, which is hoped to be as large as possible. A higher score on the "life and death" variable means that people have more traditional views about the beginning of life (souls cross life and death in cycles, each life is not unique).

Like attitudes towards contraception, attitudes towards abortion are linked to perceptions of abstinence (abortion being more acceptable to people who think abstinence rules are difficult to obey). As opposed to contraception, tolerance of abortion is linked to how people envision the beginning of life: respondents who have a cyclical (traditional) vision of life and death are more accepting of abortion. Opinions on abortion are also related to people's perception of the role of God in fertility matters: 
people who think individuals take fertility decisions (and not God) are less tolerant towards abortion.

\section{Discussion}

Altogether, we see that the same social factors seem to shape attitudes towards both contraception and abortion in the villages. Indeed, being in situations that are perceived as legitimate grounds for using birth control in the traditional meaning system on reproduction (wanting to limit the number of births when one is poor, wanting to space births when married) lead people to think more favourably of either means of birth control. Some features distinguish opinions on abortion and contraception in the villages, however: education has a strong positive impact on the acceptance of contraception, but has no such effect on attitudes towards abortion. Also, those most commonly affected by "shameful" pregnancies today (young people) are especially favourable to abortion, but are not necessarily more open to contraception (all other things being equal). In other words, in the villages, recourse to abortion is more frequently the choice of the "victim" and contraception is more often the option of those who have some education, but both sets of people see the use of birth control as especially legitimate in certain situations: for married people (when sex is OK) and for poor people (when birth limitation is OK). The underlying ideals are to resort to abstinence before marriage, and to not limit births unless constrained by resources; those ideals are part of the traditional meaning system of reproduction. In fact, animists, who are likely to be more convinced of these ideals, are more opposed to contraception than individuals of other religions in the villages. On the other hand, there is no difference in attitudes towards abortion by religion in the villages, perhaps because most villagers, even those declaring a revealed religion, still hold a traditional (animist) vision of life and death, and are thus relatively open to abortion as an emergency solution to hide "shameful" pregnancies.

Higher educational levels are linked to a greater approval of contraception in the city too. Contrary to the villages however, being married makes no difference to opinions on contraception. The idea of birth control thus seems to be accepted by people in all situations (unmarried and married people alike) in the city, although not for people in all situations. Remember that city residents think, like villagers, that contraception is less appropriate for unmarried people! We see here a dissonance between meanings and practices: a fair proportion of the urban population does not think contraception is appropriate for unmarried people (like in the villages), while unmarried people who are commonly having sex are as open to the use of contraception as any other individual (unlike in the villages). Ideals on premarital sex seem to be 
similar in the city and the villages, unlike premarital sexual behaviours. Religion and poverty levels do not make a difference when it comes to attitudes towards contraception in the city. This can be explained by the fact that traditional ideals of high fertility have all but disappeared in the city: limitation ideals are widely shared. On the other hand, women are markedly more supportive of contraception than men in the city than in the villages. We can interpret this last result as the mark of the emerging power of urban women, who increasingly define their birth control needs independently of men's perceptions of reproduction. Altogether, given the progress made by limitation ideals and women's empowerment in the city, one would expect the supporters of contraception to be much more numerous in the city than in the villages. And in fact, the prevalence of modern contraceptive use (at least among married people) is much higher in the city. But resistance against contraception for unmarried people remains similar in the urban and rural survey: ideals on premarital sex seem to have changed more slowly than behaviours in the city.

The social factors structuring attitudes towards abortion in the city are different from those structuring attitudes towards contraception and abortion in the rural site, and partly different from those shaping attitudes towards contraception in the city. Christians are more opposed to abortion in the city than individuals of other religions, although this was not the case in the villages: the world vision proposed by Christianity obviously has a stronger footing in the city, where traditional beliefs are much weaker. In the Christian vision of life and death, each individual life, once it has started, is unique and precious, and pregnancies should thus not be terminated. Accordingly, Christians are more opposed to abortion. But our qualitative data indicate that most people in Ouagadougou, whether Christian or not, share this representation of abortion as a murder (unlike what we observed in the villages). The greater disapproval of abortion in the city could be due less to the advances of Christianity, than to a diffusion of individualistic ideals picturing each individual at the center of his/ her life and controlling his / her destiny. We saw indeed that villagers holding a more individualistic vision of life (and believing for example that reproductive decisions are in individuals', not in God's hands) also condemn abortion more severely. Gender equality emerges as the second structuring dimension of attitudes towards abortion in the city; not only are women relatively more sympathetic to abortion in a context where almost everybody condemns this practice, but one can hypothesize that the relative openness of the very rich and very educated on this question is an effect of more equal gender relations in this social stratum.

Altogether, meanings and practices of birth control in contemporary Ouagadougou often appear contradictory. The most striking of these contradictions is perhaps the fact that abortion is more severely condemned but much more widely practiced in Ouagadougou than in the villages nearby. How can we explain this contradiction? We 
saw that pre-marital and marital sexuality is increasing in West African cities, a phenomenon which can be related to changes in the social dynamics of marriage, to the tightening of conjugal links at the expense of lineage relations. But while people living in West African cities want to find their own partner, wait until they find a suitable one, try to attract the best catch on the marriage market, and have premarital sex in the process, abstinence ideals seem to be slower to change. We saw that the acceptance of contraception is linked to more relaxed views towards premarital abstinence. This gap between the representation and practice of sexuality explains why contraception is not used in many pre-marital sexual relations, resulting in a higher occurrence of accidental pregnancies among young people, and thus a greater recourse to induced abortion in West African cities. But at the same time, the increase in individualistic ideals characterizing these societies explains that abortion has become more heavily stigmatized: abortions have become murders of individual lives. The combination of these different changes explain why the practice of abstinence is on the decline (new conjugal ideals), why contraceptive use is not diffusing faster (ideals about premarital abstinence are slower to change), why accidental pregnancies and thus induced abortion are on the rise, and why, at the same time, attitudes to abortion have become more conservative (rising individualistic ideals).

We propose to attribute these diverse trends, despite their apparently contradictory nature, to what N. Elias called the "civilization process" (1939). His analysis is based on historical Europe (and especially historical France), but the principles he expounds can be applied to other societies ${ }^{4}$. N. Elias shows (and M. Foucault 1976, 1984, 1997 develops these arguments further) how the management of individual instincts and desires changes with an increase in the division of labour. Societies characterized by a relatively low division of labour have rigid hierarchies; rulers and servants / slaves, even if they live together, cannot be confused. Rulers depend little on the lower classes, and use their physical force and their prestige to enforce order and to exact resources from their subjects. Rules of individual behaviours are known to all: one should avoid certain behaviours by respect for social superiors. But given that punishments are rather random (when a member of the upper class happens to personally catch a faulty member of the lower class), individuals of the lower classes have considerable freedom in applying these rules, provided they are relatively discreet. With the development of the division of labour, and later, of an administrative state, the ruling class becomes in fact much more dependent on the lower classes for its survival; social mobility increases. Also, the use of violence becomes the monopoly of the state. A new, more subtle, means has to be found to exercise power over individuals' desires. Little by little, rules of individual behaviour are internalized through the education of children by

\footnotetext{
${ }^{4} \mathrm{~N}$. Elias points to the different forms the process has taken in various European nations, and sometimes contrasts the historical developments in Europe with those taking place in China.
} 
their parents. New rationales (like hygiene) explain why one should avoid certain behaviours, and individuals keep themselves their own behaviour in check; conformism and mass behaviours appear. As an outcome of this internalization process, each individual exercises strict control over his or her sexuality, display of nudity, eating habits, forms of speech, etc.

In African social organizations, power was traditionally managed by the elders of family lineages (Lesthaeghe 1989). By arranging marriages and allocating young women, elders not only kept young men in line, but also created useful economic and political alliances between lineages, and perpetuated the existence of certain castes. The urban African context (and the villages as well to some extent) is characterized today by an increasing division of labour; the younger generations and women have acquired more power, and social mobility has increased. Young people of both sexes have greater latitude in choosing their partner (Bledsoe and Pison 1993), and competition on the marriage market, a place of social mobility, is fierce; the diffusion of premarital sex can be related to this competition. At the same time, the individualistic world vision (including perception of abortion as murder) brought by the Christian religion and the Western worldview more generally is booming in urban Africa. Concurrently, rules on sexuality seem to be becoming stricter; older ethnographers of African societies describe quite liberated sexual mores, which may seem surprising, given the weight of abstinence in contemporary African morality (see for example Caldwell 1991, 1992). Among the Mossi in Burkina Faso, for example, older ethnographers mention the custom of rollendo (Lallemand 1977): unmarried young girls and boys were allowed to flirt and were taught non penetrative sexual techniques. Married women sometimes sneaked away to meet their old rollendo, and this was all accepted as long as the couple remained discreet and that no "shameful" pregnancy occurred. During our own qualitative investigation in the village, only a few older respondents remembered this outdated custom: today's young girls and boys are just supposed to abstain.

Obviously, the question of the "individualization" of the African continent is one that we cannot begin to address here. We merely would like to suggest in the present paper (whose focus is methodological) that the diverse and apparently contradictory changes observed today in the area of reproduction in contemporary (urban) West Africa can be attributed to some larger and coherent social change driven by a change in the structure of power relations between different social groups (old and young, men and women), as predicted by a theory which is central to the historical and sociological disciplines. 


\section{Conclusion}

This research has demonstrated the value of using a mixed-method study design to approach the relationship between "values", as demographers would say, and reproductive practices. Sometimes, like in rural West Africa, meaning systems evolve little over a period of time and are well-documented: a review of the existing qualitative literature may be sufficient. But other contexts, such as urban West Africa, are sparsely documented or experience rapid social change: new qualitative investigations may then be necessary. In our case, the qualitative stage of the research helped us define a range of interrelated practices which should be considered together (sexual practices, contraception and abortion), and a range of beliefs to be taken into account to understand these practices. Note that a too narrow focus on one specific study site may hide the importance of certain dimensions: for instance, we understood the importance of gender relations in explaining birth control practices only when working on the urban site. Once we had defined the dimensions of our study topic, we designed the quantitative survey instruments to measure each of them; the qualitative results helped us craft appropriate questions. Our study shows, however, that staying too close to one's qualitative results when drafting the quantitative questionnaire is likely to prevent future comparisons (one of the strengths of quantitative data): from the start, such a comparative aim should balance the need for contextualization. This balance can be achieved by designing a set of common core questions, associated with context-specific modules if necessary. The quantitative survey data confirmed and generalized some of the relationships uncovered in the qualitative investigation. For example, our two qualitative investigations seemed to show that people condemned abortion more severely in the city than in the villages, and the quantitative data clearly confirmed this hypothesis. But ultimately, our study also shows that to move from description to understanding, we must arrange all the complex relationships observed, both in the qualitative and quantitative materials, on the basis of some existing wider (sociological or anthropological) theory.

\section{Acknowledgements}

I would like to thank the Université d'Enseignement et de Recherche en Démographie at the University of Ouagadougou who supported this research, and my colleagues Georges Guiella and Abdoulaye Ouédraogo who coordinated data collection for the urban abortion study. I thank Noemie Oswalt for data analysis and Catriona Dutreuilh for editing. I also thank Laura Bernardi and Inge Hutter for organizing the workshop on "Anthropological Demography" at the Max Planck Institute for Demographic Research, 
Rossier: Attitudes towards abortion and contraception in rural and urban Burkina Faso

and for giving me with feedback on this work. Funding for this paper was provided by: a Population Council Dissertation Fellowship 2000-2001; a Mellon Foundation Grant to the Department of Demography at UC Berkeley; Université d'Enseignement et de Recherche en Démographie at the University of Ouagadougou; Rockfeller Foundation Grant n RF99040\#102. 


\section{References}

Baya B., Guiella G., Ouedraogo C. and Pictet G. 1998. Community Health Laboratory, Bazega, Burkina Faso: Evaluation Report, UERD, University of Ouagadougou.

Beguy D. and F. Ametepe. 2004. "Utilisation de la contraception moderne et recours à l'avortement provoqué : deux mécanismes concurrents de régulation des naissances ?” Paper presented at Santé de la reproduction au Nord et au Sud : de la connaissance à l'action, Chaire Quételet, Louvain-la-Neuve, 17-20 novembre.

Benin H. 1985. "Determinants of opposition to abortion.” Sociological Perspectives 28: 199-216.

Bledsoe C. and G. Pison (eds). 1993. Nuptiality in Sub-Saharan Africa : contemporary anthropological and demographic perspectives. Oxford : Clarendon Press.

Bleek W. 1981. "Avoiding shame: The ethical context of abortion in Ghana.” Anthropological Quarterly 54(4): 203-209.

Bonnet D. 1988. Corps Biologique, Corps Social: Procréation et Maladies de l'Enfant en Pays Mossi. Paris: Editions de l'ORSTOM.

Bonnet D. 1994. “L'éternel retour ou le destin singulier de l'enfant.” L'Homme 34(3): 93-110.

Bruyer A. 1997. "Comment l'esprit va au mort. De la constitution des principes de la personne jusqu'à leur agencement post mortem.” Social Anthropology 5(3): 293311.

Caldwell J. 1991. "The destabilization of the traditional Yoruba sexual system." Population and Development Review 2: 229-262.

Caldwell J. 1992. "The family and sexual networking in sub-saharan Africa : historical regional differences and present-day implications.” Population Studies 3: 385410.

Cook E., Jelen T. and Wilcox C. 1993. "Measuring public attitudes on abortion: Methodological and substantive considerations.” Family Planning Perspectives 25(3): 118-145.

Desgrées du Loû A., P. Misellati, I. Viho, and C. Welffens-Ekra. 1999. "Le recours à l'avortement provoqué à Abidjan: Une cause de la baisse de la fécondité?" Population 54(3): 427-446. 
Elias N. 1939. Uber den Prozess der Zivilisation. Volume 1. La civilisation des moeurs, Paris : Calmann-Lévy, 2002. Volume 2. La dynamique de l'Occident. Paris : Presses pocket, 2003.

Foucault M. 1976. Histoire de la sexualité. 1. La volonté de savoir. Paris: Gallimard.

Foucault M. 1984. Histoire de la sexualité. 2. L'usage des plaisirs. Paris: Gallimard.

Foucault M. 1997. Histoire de la sexualité. 3. Le souci de soi. Paris : Gallimard.

Guiella G., A. Ouedraogo and C. Rossier. 2003. Etude quantitative et qualitative des avortements provoqués et de la contraception à Ouagadougou, Rapport scientifique, Unité d'Enseignement et de recherché en Démographie (UERD), Université de Ouagadougou.

Guillaume A. 2003. "The role of abortion in the fertility transition in Abidjan (Côte d'Ivoire) during the 1990s." Population 58(6): 657-685.

Guillaume, A. and Desgrées du Loû A. 2002. "Fertility regulation among women in Abidjan, Côte d'Ivoire: Contraception, abortion or both?” International Family Planning Perspectives 28(3):159-166.

Hammel E. 1990. “A theory of culture for demography.” Population and Development Review 16(3): 455-486.

Henshaw S. K. et al. 1998. "The incidence of induced abortion in Nigeria." International Family Planning Perspectives 24(4): 156-164.

Institut National de la Statistique et de la Démographie (INSD) et Macro Inc. 2004. Enquête Démographique et de Santé, Burkina Faso 2003. Calverton (Maryland): Macro International.

Johnson-Hanks J. 2002. "The lesser shame: abortion among educated women in southern Cameroon”, Social Sciences and Medicine 55: 1337-1349.

Kirk D. and B. Pillet. 1998. "Fertility in Sub-Saharan Africa in the 1980s and 1990s." Studies in Family Planning 29(1): 1-22.

Kobiane J.F. and A. Soura. 2003. http://www.issp.bf/opo/Produits/Datasecur/ NoteProxy.pdf

Lallemand S. 1977. Une Famille Mossi. Recherche Voltaique 17. Paris: Centre National de la Recherche Scientifique.

Lesthaeghe R. (ed). 1989. Reproduction and Social Organization in Sub-Saharan Africa. Berkeley: University of California Press. 
Ouédraogo C. and A. Ouédraogo. 1997. Enquête Qualitative de Base sur les Opinions en Matière de Reproduction. Rapport scientifique. Ouagadougou (Burkina Faso): UERD.

Ouédraogo C. 2000. "Femmes Africaines : A la Recherche de leur Statut.” Paper presented at the Chaire Quételet, Louvain-la-Neuve, Belgium, 21-24 November 2000.

Page H. and R. Lesthaeghe (eds). 1983. Child-Spacing in Tropical Africa: Tradition and Change. London: Academic Press.

Pictet G. and C. Ouédraogo. 1999. "Fertility Regulation in Rural West Africa: Is Modern Contraception a Reasonable Alternative to Abortion?” Paper presented at the Population Association of America annual meeting, New York, March 2527.

Poirier J. and G. Guiella. 1996. Fondements Socio-Economique de la Fécondite chez les Mossi du Plateau Central (Burkina Faso). Les Travaux de l'UERD 1, Ouagadougou (Burkina Faso): UERD, University of Ouagadougou.

Renne E. 1996. "The pregnancy that doesn't stay: The practice and perception of abortion by Ekiti Yoruba women.” Social Science and Medicine 42(4): 483-494.

Renne E. 1997. Changing Patterns of Child-Spacing and Abortion in a Northern Nigerian Town. Working Paper Series $n^{\circ}$ 97-1. Princeton (NJ): Office of Population Research.

Rossier C. 2002. Measure and meaning of induced abortion in rural Burkina Faso. Unpublished PhD dissertation. UC Berkeley: Demography.

Rossier C. 2005. "Les attitudes face à l'avortement en Suisse.” Chapter in J.-M. Legoff, C. Sauvain-Dugerdil, C. Rossier, J. Coenen-Huther, Maternité et parcours de vie. L'enfant a-t-il une place dans les projets de vie des femmes en Suisse? LaboDémo, Bern : Editions Peter Lang.

Rossier C., G. Guiella, A. Ouédraogo and B. Thiéba. 2006. "Estimating clandestine abortion with the confidants method. Results from Ouagadougou, Burkina Faso.” Social Science and Medicine 62(1):254-266.

Rossier C. 2006. "L'avortement: un secret connu de tous? Accès aux services d'avortement et implication du réseau social au Burkina Faso.” Sociétés contemporaines 61: 41-64.

Rossier C. 2007. "Abortion: an open secret? The abortion process and social network involvement in Burkina Faso.” Reproductive Health Matters 15(30): 230-238. 
Rossier: Attitudes towards abortion and contraception in rural and urban Burkina Faso

Spira A., N. Bajos and the ACSF group. 1993. Les comportements sexuels en France : rapport au ministre de la recherche et de l'espace. Agence nationale de recherches sur le Sida ; sous la dir. de l'INSERM. - Paris : La Documentation Française. 